\title{
Can populations be healthy? Perspectives from Georges Canguilhem and Geoffrey Rose
}

\author{
Élodie Giroux ${ }^{1}$ (1)
}

Received: 16 May 2021 / Accepted: 30 August 2021 / Published online: 20 October 2021

(C) Springer Nature Switzerland AG 2021

\begin{abstract}
Canguilhem criticized the concept of "public health": health and disease are concepts that only apply to individuals, taken as organic totalities. Their extension to a different level of organization is purely metaphorical. The importance assumed by epidemiology in the construction of our knowledge of the normal and the pathological does, however, call for reflection on the role and the status of the population level of organization in our approach to health phenomena. The entanglement of the biological and the social in human life and in contemporary societies justifies this level of analysis for better understanding the complexity and the interaction of health determinants both at the level of individuals and their interactions and at that of the population. But is this population level just a useful level of analysis that makes it possible to bring to light the social determinants of health at the individual level, or does it rest instead on characteristics of the population that are irreducible to individual characteristics, but which are nevertheless important for understanding and taking action with respect to both population and individual health? Defending this second alternative, I show how the epidemiological point of view, and in particular that of social epidemiology, leads us to rethink the possibility of a concept of "population health" that is not reducible to the sum of individual instances of health.
\end{abstract}

Keywords Population health · Public health $\cdot$ Georges Canguilhem · Geoffrey Rose $\cdot$ Social epidemiology $\cdot$ Population thinking

Élodie Giroux

elodie.giroux@univ-lyon3.fr

1 Faculté de Philosophie, Institut de Recherches Philosophiques de Lyon, Université Jean Moulin Lyon 3, Lyon, France 


\section{Introduction}

"The study of disease as a mass phenomenon differs from the study of disease in the individual primarily in respect to the unit of investigation. It is early appreciated that the herd, the crowd or the community is not a simple aggregate of the persons comprising that grouped population, but that each universe of people is an entity, a composite that possesses as much individuality as does a person." (Gordon, 1950, p. 158)

John E. Gordon (1950), Professor of epidemiology and preventive medicine (1946-1958), Department of Epidemiology, Harvard University School of Public Health, Boston, Massachusetts.

When one talks of health and disease, it's generally in relation to individuals. Nevertheless, the notion of "public health" could well imply the idea of a form of health proper to the population. In this article, I aim to consider whether health may be the property of other entities than individuals and, more precisely, to consider the arguments that could be advanced to justify a concept of "population health". This question has hardly been addressed in the debates about the concept of health and disease in the philosophy of medicine; these have concentrated instead on the issue of their objectivity. ${ }^{1}$ And yet, we commonly use a notion of population health that does indeed seem to lay at the foundation of public health. Is this use purely metaphorical?

In order to address this question, I will anchor my reflection in a dialogue with the French philosopher and physician, Georges Canguilhem. Canguilhem is less well known by Anglo-American philosophers than his student Michel Foucault who was inspired by the importance Canguilhem gave to the concept of normativity in his philosophy of biology and medicine. But recent work has done a lot to introduce Canguilhem's thought to Anglo-American audiences, particularly in philosophy of medicine. ${ }^{2}$ Canguilhem is the author who has gone the furthest in defending an individualist conception of health and disease and in criticizing the use of these notions at the level of the population. For him, diseases are neither beings, nor simple quantitative differences; they are normative differences that only affect certain types of beings: individuals considered as organic totalities. In a critical analysis of the notion of public health, he remarks that at the population level, it is preferable to use the term "hygiene" or "salubrity": "The hygienist endeavors to govern a population-individuals are not his business. "Public health" is a contestable term-“"salubrity", would be more appropriate" (Canguilhem, 2012b, p. 49). Understanding the term "public" in the sense of the visible, rather than "of or concerning

\footnotetext{
1 Concerning these debates, see for example (Kingma, 2017; Murphy, 2008). A debate has recently occurred around the concept of eco-systemic health applied to the planet, but very few works discuss the application of the notion of health to populations. See nevertheless (Arah, 2009; Giroux, 2008a; Schramme, 2015; Valles, 2018) as important exceptions and this paper is a revised and expanded version of an earlier chapter on this topic published in French in 2008 (Giroux, 2008b).

2 See (Méthot, 2020a). See also (Giroux, 2010).
} 
the people as a whole", ${ }^{3}$ he considers that health is often the opposite of a public phenomenon. Indeed, according to the definition borrowed from the surgeon, René Leriche, it consists in "life in the silence of the organs" (Canguilhem, 1991, p. 243). But it's above all his introduction of the concept of "biological normativity" to characterize health which leads him to argue that the individual organism is the only level of organization at which this concept may legitimately be used.

Adopting Canguilhem's concept of philosophy as the work of reopening problems (Canguilhem, 1991, p. 35), my objective here is to reopen the problem of the levels of organization to which the concept of health applies, drawing primarily on reflections undertaken in social epidemiology, a field which has recently been institutionalized as a distinct subdiscipline of epidemiology. ${ }^{4}$ In his medical thesis published in 1943 under the title Essay on some problems concerning the normal and the pathological, Canguilhem sought a foundation for his individualist interpretation of health phenomena in biology and, more specifically, in physiology and in the theory of evolution on which I will focus. In the first part of this paper, I reevaluate this foundation in light of recent analyses in philosophy of biology. These suggest that the link between "individuality" and "organism" may not be as tight as Canguilhem affirmed. The central role of the individual organism in biology and in medicine will then be called into question, leaving more space for the population and for the population level in general. In the second part, I adopt the perspective of epidemiology, a discipline concerned with health phenomena inasmuch as they affect the population, in order to consider the arguments that epidemiologists have developed in favour of the concept of "population health". Although there are good reasons to discuss the concept of health taking into account the standard disciplinary boundaries (between physiology, immunology, the theory of evolution, etc.), I will try instead to follow the links across disciplines. 5

Since Canguilhem's 1943 publication, epidemiology has assumed an important role in the constitution of knowledge about health and disease. But this new role has not necessarily led to the promotion of the autonomy of the populational level of analysis. However, certain epidemiologists writing since the 1950s-but also more recently those who have promoted the development of social epidemiology as a subdiscipline of epidemiology - have laid claim to the specificity of epidemiology, relative to clinical medicine: epidemiology is to the population what the clinic is to the patient, that is to say, the diagnostic procedure for the populational level. ${ }^{6}$

\footnotetext{
3 This is one of the definitions for "public" by the Oxford English Dictionary.

4 Social epidemiology as an institutionalized subdiscipline of epidemiology is often identified as emerging in the 1980s, but it is not very clear-cut. See for example (Galea \& Link, 2013; Krieger, 2001).

${ }^{5}$ I defended elsewhere an interdisciplinary concept of health relying on the sciences of physiology, evolutionary theory and epidemiology (Giroux, 2015).

${ }^{6}$ In the same article in which one finds the citation placed as an epigraph to this text, John Gordon writes: "This discipline, epidemiology, is the counterpart of diagnosis and bears precisely the same relationship to public health practice as does diagnosis to clinical management" (Gordon, 1950, p. 198). The importance accorded to the population level within epidemiology is at the heart of the vision of social epidemiology put forward for the development of this field as an institutionalized subdiscipline (Berkman \& Kawachi, 2000).
} 
For these epidemiologists, concepts like "social capital", "social disorganization" or "herd immunity" make sense only at the level of the population. It would be therefore legitimate to speak of health in relation to populations. This is, moreover, the position explicitly defended by a recent current of thought in favour of a "population health approach". 7 It is these claims that I aim to examine: do they imply that we should reject the exclusivity accorded by Canguilhem to the individual organism regarding the concepts of health and disease? The question of the ontology of public health has strong implications for the debate between collectivists versus individualists in the philosophy of public health, but also for the way public health interventions are conceived and designed—as we are witnessing with the Covid 19 pandemic. The current debate on herd immunity is a perfect example. Even if this debate is out of the scope of this paper, the discussion I have on the ontology of public health has some direct implications on it.

\section{An Examination of Canguilhem's individualist conception of health}

\subsection{Health as individual normativity}

It's to resolve the difficulties linked to what Canguilhem calls the "positivist dogma" and to go beyond the opposition between qualitative (or ontological) and quantitative (or physiological) approaches to health and disease phenomena that he introduces the concepts of "capacity" and "biological normativity". ${ }^{8}$ According to the positivist dogma, whose limits and insufficiencies Canguilhem endeavour to demonstrate in the first part of his 1943 medical thesis, health and disease are not considered as opposed realities. They only differ from one another by degrees: disease is defined in a purely quantitative way. From this perspective, the concepts of the normal and the pathological, which are fundamental in medicine, are objective and non-normative. Canguilhem shows, however, that quantitative modification does not suffice to delimit the normal from the pathological. By confirming the continuity and the homogeneity of the relation between the normal and the pathological, this dogma does away with the very object of medicine: the negativity of disease. For Canguilhem, there is an alteration in disease that introduces a qualitative difference. The ill individual feels "different". The disease is not simply a distance with respect

\footnotetext{
7 The notion of "population health" is thought to have been introduced in a Canadian context by Evans and Stoddart (Evans \& Stoddart, 1990). It would then appear to have been further developed by Kindig and Stoddart (Kindig \& Stoddart, 2003). The main idea is that of insisting on a significant difference between studying the health of a group and the health of an individual. This notion is not, however, dissimilar to that of "saúda collectiva" (collective health) used and promoted from the late 1970s onwards in Latin American (Diez Roux, 2016).

8 On the concept of "biological normativity", see Canguilhem (1991). On the definition of health as "capacity" or as "possibility" or "power", Canguilhem says: "[w]hat characterizes health is the possibility of transcending the norm, which defines the momentary normal, the possibility of tolerating infractions of the habitual norm and instituting new norms in new situations." (1991, p.196-197); and "[h]ealth is a regulatory flywheel of the possibilities of reaction. Life is usually just this side of its possibilities, but when necessary it shows itself above its anticipated capacity.”, (1991, p.198, my italics).
} 
to a statistically or experimentally defined norm, but the emergence of a "new individual norm" (Canguilhem, 1991, p. 194) which constitutes "another way of life" (Canguilhem, 1991, p. 89). Canguilhem strongly associates the concept of normativity to that of the organic totality: only the individual organism apprehended as a totality constitutes a sufficiently well-organized entity for a difference between the normal and the pathological to appear. A quantitative modification is only pathological to the extent that it reflects an alteration, a qualitative modification of the organism taken as a "whole": "In the final analysis, would it not be appropriate to say that the pathological can be distinguished as such, that is, as an alteration of the normal state, only at the level of organic totality, and when it concerns man, at the level of conscious individual totality, where disease becomes a kind of evil?" (Canguilhem, 1991, pp. 87-88). A form of organic holism is therefore the response Canguilhem offers to the limits and difficulties encountered in the reductionism of the positivist dogma.

\subsection{Biological foundations of individual normativity}

To support his thesis regarding health as normativity and its irreducibly individual character, Canguilhem draws extensively on the holistic conception of the organism defended by Kurt Goldstein (1878-1965). This German psychiatrist and neurologist argues for and defends this conception on the basis of observations made on patients suffering from brain injuries during the First World War (Canguilhem, 1991, pp. 181-201; Goldstein, 1939). But the originality of Canguilhem compared to Goldstein is that he introduces the notion of "normativity", deriving it from biological science on the basis of, firstly, a defence of a biological and organic concept of individuality, and, secondly, his reading of the Darwinian theory of evolution. ${ }^{9}$

So, firstly, Canguilhem conceives individuality as an "organic totality" and thus associates individuality to the organism. Although these two concepts are often assimilated, it is nevertheless important to distinguish between the "organism" as a "level of organization" (cell, organism, family, society, biocenosis, etc.) and the "individual" inasmuch as it designates an "ontological status", the degree of ontological unity of the entity in question. For Canguilhem, it is only at the level of the organism that the concept of individual is pertinent. It's the functional convergence of parts in the whole that constitutes the authentic "whole" (designating here an ontological unity) and which means that this true "whole" is more than the simple sum of its parts. Only such a "whole" merits to be called an "individual" and only the organism (understood as a level of organization) merits being conceived as a totality. The other levels of organization, seen as potential candidates for individuality, are not true totalities. The cell is a totality which can also be a "part". As for society, it is not a sufficiently integrated totality to be considered an authentic "whole"; its unity, like its finality, comes from the outside, whereas they are immanent to the biological organism. As Canguilhem himself says: "[c]ertainly, a society

\footnotetext{
9 A significant part of my analysis here is inspired by an article of Jean Gayon (Gayon, 1998).
} 
bears some resemblance to what is organic, since it is a collectivity of living beings. We cannot, properly speaking, decompose a society, but if we analyze it, which is a very different thing, we discover that while a society is a collectivity of living beings, this collectivity is neither an individual nor a species. It is not an individual, because it is not an organism endowed with a purpose and a totality that are obtained by a specialized system of devices of regulation; it is not a species, because it is, as Bergson says, closed" (Canguilhem, 2012c, pp. 76-77). The refusal to apply the category of the individual to society is also a critique of the thought of Auguste Comte and his positivism. Auguste Comte does indeed apply the concept of health to society and bases this application on an analogy between society and organism. It's on the refusal of this analogy that Canguilhem would appear at least partly to base his opposition to a concept of health at the level of the population. But beyond the fact that it is important to distinguish the concepts of "society" and "population", the possibility of thinking about population health without recourse to this analogy is also worth considering. ${ }^{10}$ The problem perhaps resides not so much in the analogy between society and organism but rather, as we will see, in an overly restrictive understanding of the concept of the individual.

Secondly, Canguilhem (1991, pp. 79-81, 88-91) finds in the theory of evolution by natural selection a biological basis for individual normativity. For Canguilhem, far from rejecting every notion of norm outside of biology, the Darwinian theory of selection shows the existence of a normativity in the living: "[i]n suggesting that individual variations, deviations in structure of instinct, are useful because they yield a survival advantage in a world in which relations of organism to organism are the most important of all causes of change in living beings, Darwin introduced a new criterion of normality into biology, a criterion based on the living creature's relation to life and death. By no means did he eliminate normality from consideration in determining the object of biology" (Canguilhem, 1988b, p. 137). ${ }^{11}$ Further, what Méthot (Méthot, 2020b, p. 174) ${ }^{12}$ describes as the "Darwinian perspective informed by mutationism and open to the influence of the environment" adopted by Canguilhem allows him to establish a tight link between individual variability and vital value. Mutationism leads Canguilhem to maintain the vital and creative role of novelty and variation, and to underline the importance of the relation of the organism to its milieu for the vital meaning that this variation acquires (emergence of a new species for a mutation or the normal or pathological character of an anomaly). From a perspective which is opposed to typological or Platonic thought and close to what the biologist and historian of biology, Ernst Mayr, later called "population

\footnotetext{
${ }^{10}$ R. G. Wilkinson proposes to talk of "unhealthy societies". His arguments are very close to those that I will develop on the basis of social epidemiology (Wilkinson, 1996).

11 I have taken the liberty of translating "normalité" as "normality", rather than as "morality", as in the published translation. Similarly, Canguilhem (1991, p. 263) elsewhere writes: [t]he norm is the form of divergence maintained by natural selection".

12 Méthot's chapter offers a detailed and in-depth analysis of the complex links between Canguilhem, Darwinism, and the theory of natural selection (Méthot, 2020b).
} 
thinking", to characterize the mode of thought at work in evolutionary biology, ${ }^{13}$ Canguilhem affirms that "irregularity and anomaly are conceived not as accidents affecting an individual but as its very existence" (Canguilhem, 2008, p. 125).

One can also consider that the reference to the Darwinian theory of natural selection reinforces the importance accorded to the individual organism in the sense that Darwin seems to have favoured natural selection at the level of individuals. ${ }^{14}$ The idea is as follows: the level of organization on which natural selection focusses must consist of entities that possess a sufficiently strong ontological unity to be capable of reproduction. Selection presupposes, as much as it constitutes, a benefit for the individual, which is selected because of some variation or other in its traits. The selected entity would be the entity to which these evolving traits are beneficial, with benefit being defined in terms of survival and reproduction at the level of the organism. The process of natural selection demands the existence of entities capable of reproduction. That the individual organism is the level of organization at which natural selection operates would thus be a way of grounding this tight link between normativity and organic individuality.

\subsection{The place of the organic individuality and of normativity in biological thought: some controversies after the 1943 medical thesis}

The theses we have just presented, and which allow Canguilhem to give a biological and individualist basis to the concept of normativity in his 1943 medical thesis, have since been the object of debates in both biology and philosophy of biology.

A first subject of controversy concerns the idea that a normativity of the living would be given in and by natural selection. Does the theory of evolution reaffirm the ineluctable character of the concept of norm and, more generally, of a normativity in biology, as Canguilhem affirms? The question has been dealt with since in the context of a debate about the definition and the normativity of the concept of biological function (Buller, 1999; Gayon \& de Ricqlès, 2010; Krohs \& Kroes, 2009). Some defend the possibility of a non-normative concept of biological function: the function in a system is nothing other than the causal role it plays in the system. Others defend a normative (often also described as etiological) concept, the normativity of which does indeed depend on natural selection: the function of the heart is to make the blood circulate because this effect is the result of natural selection. The concept is normative in the sense that one can derive from this conception the idea that one expects the heart to make the blood circulate. I will not attempt to deal here with this rich and complex debate, for I will settle with the observation that the debate

\footnotetext{
13 Mayr opposes "population thinking" to the "typological thinking" characteristic of biology prior to the theory of evolution. "Population thinking" accords a central place to individual variation rather than to the essence or the type. It is important to note that it is not necessarily a way of thinking that favours the population level for itself, but it does use it in the framework of a statistical approach for thinking and valorizing individuality and variation. As we will see later, epidemiology typically subscribes to this mode of thought without necessarily valorizing the population level as such. See (Giroux, 2010; Giroux, 2008a).

14 On the central place of the organism in the Darwinian conception of evolution, see (Ariew, 2008).
} 
has crystallized around the question of the normativity of the concept of biological function.

A second controversy concerns the object of my study more directly: the question of the tight link between biological normativity and the individual organism. Does the theory of natural selection link this possible normativity, arising from the survival advantage, to the individuality of an organism? In Canguilhem (1988b, p. 137), cited above, it seems to be the case: the relations of organism to organism are said to be "the most important of all causes of change in living beings". From the late 1960s onwards, the question of the units and levels at which natural selection may be said to occur has been the object of debate in evolutionary biology. It is a question of ascertaining which entities are selected and of clarifying, within these entities (properties, traits, etc.), what makes them possible objects of selection. A breakthrough was made by distinguishing two selection concepts: the selection of objects or of entities (selection of) and the selection of properties or traits possessed by the entity (selection for). The selection of objects refers to the effects of certain processes, whereas the selection of traits describes the causes of change, the causal property that explains the process of survival and differential reproduction (Sober, 1984a). But it is far from certain that the individual organism is the entity that benefits from evolving traits (selection for), or at least that it is the only one to be the object of selection (selection $o f$ ). For George Williams and Richard Dawkins, traits evolve because they primarily benefit the genes that code for them (Dawkins, 2016; Williams, 1966). In this conception of evolution and natural selection, the relations of gene to gene are the most important and genes are the objects of selection. Other philosophers of biology have showed that, if it is individual organisms that are selected, it becomes difficult to explain altruistic behaviours that benefit the group and not the individual. To account for the presence of altruistic behaviours, it would seem necessary to envisage the existence of selection phenomena at the level of groups or species. This latter approach re-opens the possibility of attributing a certain ontological unity to entities at higher levels of selection than that of the individual organism, like species or groups (Brandon, 1982; Lewontin, 1970; Wilson \& Sober, 1989; Wimsatt, 1980).

Moreover, not without link to this question of the possibility of group selection, a debate broke out in the 1980s and 90s about the ontological status of species. This debate introduced some important transformations to the concept of the individual, defined as a "spatio-temporally defined entity", which could well be applicable also to species (Ghiselin, 1974; Hull, 1978). From this point on, the concept of the individual was no longer so tightly connected to that of the organism. For example, the notion of superorganism has been introduced with colonies of social insects such as ants, wasps and bees as paradigmatic examples. They are viewed as a special kind of biological individual arising from the specific genetics and reproductive division of labour in those colonies. ${ }^{15}$

\footnotetext{
15 For more on "biological individuals", see Wilson and Barker 2019. For a general reflection on the concept of the individual, see (Pradeu \& Ludwig, 2008). On modifications to the concept discussed in biology, see (Bouchard \& Huneman, 2013). And on individuals in the sciences in general, see (Guay \& Pradeu, 2015).
} 
The controversy over units of selection would thus appear to have redistributed the positions adopted regarding the level of selection at which natural selection operates. On the one hand, the theory of the selfish gene (Dawkins) attributes the central role to genes. On the other, the theory of levels of selection insists on the multiplicity of levels of organization at which selection operates (Wilson, Sober, Wimsatt, Brandon, Lewontin, etc.). In every case, the individual organism loses the supremacy that it at first sight possessed in the Darwinian theory of natural selection.

Nevertheless, more recent research has contributed to giving back to the organism as a whole an important place in biological thinking, both in the context of the development of other domains of biology, like developmental biology, and in the very heart of evolutionary biology (Huneman, 2010; Nicholson, 2014). So should one consider that this more recent research shows that Canguilhem, an important precursor, was right all along? In reality, it is firstly important to note with Jonathan Sholl (2020, pp. 277-278) that, despite this apparent "return of the organism", conflicting interpretations of the importance of the organism have always been presented, and furthermore, that the debate is far from closed. Above all, what is important here in our critical examination of Canguilhem's individualist conception of health is the importance assumed in biological thought since his 1943 medical thesis by reflections that make room for the population level of organization. This importance has become apparent both in the context of controversies regarding the unity of selection and the possibility of a natural selection at work between groups and in the context of discussions about the ontological status of species and the pertinence of extending the concept of the individual both above and below that of the organism (Bouchard \& Huneman, 2013). Multi-level approaches have thus been pushed to the fore in biology, and these have not been without influence on another discipline: epidemiology. They are an invitation to fresh thinking about the pertinence of a concept of health that would be valid for populations.

\section{Epidemiology: towards a concept of population health}

Leaving biology behind and turning instead to medicine, I will now examine the arguments put forward in epidemiology in favour of a return to a population perspective. At first sight, epidemiology differs from clinical medicine by the level of analysis at which its object of study is situated: it is interested in the distribution of disease and its determinants, at the level of the population. But does this level of study lead it to accord a specific and autonomous status to populations in its understanding and analysis of health phenomena and, consequently, to promote a concept of health specific to the population? At the statistical level, disease become morbidity. The epidemiologist has at their disposal different forms of evidence enabling them to evaluate the state of health of a population. Morbidity may be measured by either its prevalence or its incidence, that is to say, for a given population, the number of cases at time $t$ (prevalence) or the number of new cases over a certain period (incidence). Nevertheless, these forms of statistical measures are only, at first sight, the sum of the diagnoses of individuals. The level of measurement remains 
that of the individual. ${ }^{16}$ But it's at the level of the population, as a statistical aggregate, that one can make comparisons that authorize inferences regarding aetiology. If the level at which variables are measured remains the individual, is the level of analysis that of the population? And if so, does that open the theoretical possibility of a concept of population health? It would seem the answers we might give to these questions are relative to the concept of population employed. Epidemiology appears torn between a purely statistical concept, which defines the population as a simple "aggregate" of individual entities, and a concept which accords to the "population" an identity, and even an individuality, on the basis of its specific characteristics (geographical, social, biological).

\subsection{The centrality of the individual in modern epidemiology}

The analytic methodology used in epidemiology is comparative. Two types of aetiological study may be distinguished corresponding to two levels of comparison: studies of groups or "ecological studies" (comparison between populations) and studies of individuals (comparisons between individuals). The term "ecological", used to qualify the first type of study, indicates that the unit of analysis is the population and not the individual. ${ }^{17}$ In these studies, the parameters placed into relation with one another and whose variation one studies are environmental indicators or "collective" or "aggregated" variables: morbidity, mortality, variation of the frequency of disease as a function of time or geography. These studies make it possible, for example, to compare cardiovascular mortality in France and in the United States, and, within France itself, to bring to light important variations between the north and the south of the country. Once differences between populations and statistical associations have been brought to light, the work of analytic epidemiology is to study the meaning of the association and its possible causal value. At the ecological level, however, the causal inference raises significant difficulties: risks of bias are multiple and one also runs the risk of committing the so-called "ecological fallacy", an error present when one makes inferences for the individual level on the basis of group data (Morgenstern, 1995). ${ }^{18}$ It is important to note also that aetiological research in epidemiology was carried out on the basis of studies of individuals. ${ }^{19}$ These studies were

\footnotetext{
16 I am henceforth using "individual" to designate the "individual human being".

17 This use of the term is borrowed from sociology. It refers to a part of a social system, defined geographically, but is also used in a broader and less precise manner to distinguish group phenomena from individual phenomena.

18 The ecological fallacy arises because associations between two variables at the populational level may be different from those between two variables measured at the individual level. These differences between associations at the population and individual levels were first brought to light in sociology on the basis of differences in the coefficients of correlations (Robinson, 1950). The epidemiologist, Sharon Schwartz, showed that ecological studies were wrongly rejected on the grounds that they had committed this fallacy. But the ecological fallacy shows rather that ecological studies cannot be considered as just simplified substitutes for individual studies (Schwartz, 1994).

19 Morgenstern (1995, p. 62) emphasizes that, before 1980, ecological studies were presented in the first part of epidemiology textbooks as simple descriptive analyses; very little attention was accorded to statistical methods and to inferences.
} 
carried out in the framework of what is conventionally referred to as "modern" epidemiology, which, after the Second World War, employed more rigorous methods of inquiry and new statistical techniques borrowed from inferential statistics (Rothman, 1986; Susser, 1985). Cohort studies and case-control studies made it possible to correlate individual factors of exposure and disease, but also to quantify their correlation with precision. ${ }^{20}$ As a consequence of the importance assumed by these types of study, the individual level became central, both for measuring the variable, and for analysis and inference. Modern epidemiology is thus characterized by the centrality of individual comparison and thus also by the relegation to a secondary status of studies focussing on populations, in which causal inference is too complex. The epistemological level at which we gain the best knowledge on health and disease is considered to be the individual. The result was that, rather than being a discipline that differs from clinical studies by relying on population both as the ontological level at which health and disease could be considered as existing and as the epistemological level at which we should analyse these phenomena, modern epidemiology appears as a method in continuity with the clinical approach to disease. The primacy of the individual level in medicine, dear to Canguilhem, both epistemologically and ontologically speaking, would appear to be confirmed.

It is nevertheless important to make an observation regarding the notions of individual and population as they are used in the context of modern epidemiology. The individual is not the concrete individual of which Canguilhem spoke. ${ }^{21}$ It's a statistical construction, a "case" in a given reference class. This construction does, however, make it possible to get closer to a science of the individual and to provide useful generalizations about diseases. Indeed, the use of statistics arms one with sufficiently general knowledge while also respecting inter-individual variability. Statistical models help, moreover, to explain inter-individual variability. Only the statistical approach makes possible predictions, thus facilitating preventative action. As for the concept of population used by modern epidemiology, it would seem to be a purely statistical concept. The population is not studied for its particular identity or its individuality. What one is interested in is the aggregate, inasmuch as it makes

\footnotetext{
${ }^{20}$ Cohort studies follow, often in a prospective way, two groups of healthy individuals who differ by a level of exposure that may - and this is what the study must determine - have an effect on the frequency of the disease. Case-control studies are often retrospective inquiries, in which ill persons (cases) are selected and compared to healthy persons (controls). The prospective study of Framingham played an important role in bringing to light the principal factors in the risk of cardiovascular disease: high-blood pressure, high levels of cholesterol, smoking, obesity, diabetes, etc.

21 Like Claude Bernard, but for different reasons, Canguilhem was initially worried about the use of statistics in the domain of health. In his eyes, the recourse to statistics leads one to place parentheses around the individual ill person, the chosen object of the clinician's attention and action. The demands of number counting obscure the existential dimension of health. But then, in his later writings, Canguilhem took notice of the importance of calculating probabilities, especially when adapted to the study of the living and its variability. Indeed, in an essay on the scientificity of medicine, Canguilhem accords an important role to the epidemiological approach as such. It played as fundamental a role as bacteriology in the renewal of the epistemology of medicine and brought it into the orbit of the fields of economic and social science (Canguilhem, 1988a, p. 23). However, probably under the influence of the analyses of his student, Michel Foucault, on bio-power, Canguilhem sees above all in the statistical and population level of analysis a degeneration towards a sort of biological technology in the service of politics.
} 
it possible to calculate probabilities and to infer generalizations. Far from being considered an inherently valuable level of analysis, the population level has here an instrumental character. It is above all a useful detour for making predictions of risk at the level of individuals.

But does this modern epistemology, focussed on the individual level, represent the whole of epidemiology? Do not ecological studies and the population level in general, to be understood here as an epistemological level of analysis, provide information that is neither visible at, nor reducible to, the individual level, but which is nevertheless important and useful for the comprehension of health and disease phenomena? Moreover, at an ontological level, are there not very widespread attributes that, characteristic of a specific population, impinge on individuals in a collective manner and, as a consequence, justify a concept of health (or disease) for the population itself? If Canguilhem recognizes the influence of supra-individual determinants of individual health, like social, geographic, and economic factors, and the importance of the environment and the context of social life, that does not however lead him to consider these characteristics as constitutive of a given population, or to maintain the validity of a concept of health specific to the population. ${ }^{22}$ Whether it's social or biological, normativity, as Canguilhem conceives it, is anchored in the individual. In his eyes, the notion of health undergoes a change of meaning when its application is extended to a whole population (Canguilhem, 1994, p. 403). As I mentioned above, he prefers to retain the terms hygiene or salubrity when focussing on the population level and he further notes that these concepts constitute a "semantic departure" from the original concept of health (Canguilhem, 1988a, p. 23). ${ }^{23}$ But what do those social epidemiologists who contest what they consider to be an individualism in modern epidemiology and who defend the importance of the population at the heart of their discipline as both epistemological and ontological levels relevant for health and disease have to say (Krieger, 1994; McMichael, 1999)?

\footnotetext{
${ }^{22}$ In his article, "Diseases", Canguilhem recognizes the importance of studying diseases from a statistical point of view concerned with their appearance, social context, and evolution. This point of view makes it possible to situate the individual in their community. Nevertheless, bringing medicine closer to sociology and economics does not lead him to recognize in disease a supra-individual dimension: "whatever importance in the increase of pathological situations we should accord to patterns of life and their relations to working conditions (for example, the role of muscular exhaustion or the deregulation of functional rhythms), it is improper to confuse the social genesis of diseases with the diseases themselves. The clinical picture of diseases such as stomach ulcers and pulmonary tuberculosis is unaffected by them being the effect of individual or collective situations of distress. Even if the work of the clockmaker or the duties of the schoolboy expose defects in vision much more easily than shepherding sheep would, we would nevertheless not go so far as to say that ophthalmology patients are social facts" (Canguilhem, 2012a, p. 39).

${ }^{23}$ It is important to note, however, that Canguilhem does not really envisage the possibility of a concept of "population health", as it is defended today (see footnote 7 above). Canguilhem's semantic analysis bears instead on the concept of "public health".
} 


\subsection{Arguments for a concept of 'population health'}

Since the 1990s, a debate has been taking place at the heart of epidemiology opposing those who defend a return to the population level of analysis to those who prefer to accord primacy to the individual level. Recognizing the importance of the population level of analysis has led certain epidemiologists to give it back its central place in the discipline and to defend the necessity of a change of paradigm (Berkman \& Kawachi, 2000; Diez-Roux, 1998; McMichael, 1999; Susser \& Susser, 1996). The population is considered to be a pertinent level of organization in itself, both for measurements and for analysis and inference. For these epidemiologists, it is about returning to social medicine as a source of inspiration. ${ }^{24}$ Modern epidemiology, also called "risk factor epidemiology" (Susser, 1998) is judged reductionist; it is, in their eyes, too limited to the individual level of analysis, forgetting the interest and the benefits of ecological studies. These analyses are worth examining in the context of our reflection on a concept of population health. One finds in them three arguments in favour of this concept.

\subsubsection{The importance of population comparisons}

A first type of argument concerns the insufficiency of individual comparisons, especially in the case of ubiquitous factors. The low variability of a studied factor in a given population can lead it to go unnoticed in an individual comparison study. Consider the simple example of a population in which smoking is a massively widespread behaviour; it is not possible to compare a group of smokers and a group of non-smokers to show a difference in the incidence rate of disease between the two groups and to demonstrate the consumption of tobacco as a risk factor. The existence of heterogeneity within the studied population is thus a condition of possibility for this type of study. If the phenomenon studied is massively widespread, it is more difficult to show that it makes a difference and gives rise to an increased risk of disease, even though that it is in fact the case. This explains the importance, methodologically at least, of comparisons situated at a higher level of organization than the individual level. It is, moreover, comparisons between populations which have underpinned studies of diet in the etiology of cardiovascular diseases. ${ }^{25}$ At the individual level, no correlation can be shown. For example, within a population, it seems impossible to show any relation between an individual's diet and his level of

\footnotetext{
${ }^{24}$ They draw in particular on the social medicine developed between the two World Wars in Great Britain and the United States, notably the works of the Englishman, John A. Ryle, and the American, Iago Galdston. See, for example, (Krieger, 2001).

25 Works in comparative epidemiology at the international level, carried out notably by the American physiologist, Ancel Keys, in the wake of the Second World War, played a decisive role in understanding that cardiovascular diseases are not simple degenerative diseases but have environmental, cultural, and behavioural components (Keys, 1970; Keys \& White, 1956). The work of Keys, especially the Seven Countries Study, a multi-country epidemiological study which examined the relationship between diet, lifestyle, risk factors and cardiovascular diseases, has nevertheless been criticized for its poor methodology. See (Pett et al., 2017).
} 
cholesterol; the same thing holds for the relation between the consumption of salt and blood pressure. There are thus statistical associations that appear at the level of groups, but which are invisible at the level of individuals, and yet which are informative and useful for the prevention of cardiovascular diseases.

The invisibility, in the individual comparison, of a statistical association manifest at the level of a comparison between populations, could indicate that a populational factor, that is to say, a factor that has a global influence on the entirety of the population, such as a social or environmental factor, is playing an important role. It is possible to object, however, that, whatever the global character of the influence of the factor in question might be, its effect must also be manifest at the individual level. The impossibility of showing a statistical association at the individual level does not imply that this factor is not operative at this level or even that it exists differently at this level. Further, this impossibility may derive from a methodological limitation, notably the difficulty of quantifying certain variables at certain levels. Although the majority of variables are more easily measurable at the individual level (age, profession, income, etc.), some are very difficult to measure and quantify at this level (environmental influence, diet). The interest of the population level would thus be simply to find a way round and overcome limitations encountered in the measurement of these variables at the individual level. Can't one consider that this is just a methodological or epistemological limitation of epidemiology but does not have any ontological implication about capturing a disease at the level of the population? If that were the case, the observation of statistical associations visible at the level of the population, but invisible at the level of individuals, would not be a sufficiently strong argument to justify using a concept of population health.

\subsubsection{Properties constitutive of the population}

A second type of affirmation raises the argument to a more ontological level. For the epidemiologist, Geoffrey Rose, the population in ecological studies, is no longer considered from a purely statistical perspective. It is not a simple aggregate used to make generalizations. On the contrary, an ecological study can show that the population has its own specific characteristics, that it possesses a certain individuality. ${ }^{26}$ If one considers the distribution of cholesterol, for example, one notices great differences between individuals, but also, and above all, between populations. Differences can even be bigger between populations than within a single population. Geoffrey Rose, drawing on the work of Ancel Keys, takes the example of the comparison of the distribution curves of cholesterol of the Finnish and Japanese populations (Rose, 1992). When focussing on the level of populations considered as "wholes", one notices that the curve of the Finnish population is to the right of the curve for the Japanese population. The two curves hardly cross at all (see Fig. 1 below). As a consequence, a level considered normal in Finland would be considered abnormal in Japan.

\footnotetext{
26 The concept of individuality is to be understood here in the sense of an ontological unity rather than as a level of organization.
} 
Can this large difference between the Japanese and Finnish populations be explained by summing a multitude of differences in the health of individuals? Or alternatively, if it is the entire curve that shifts position, is that not a sign that one is dealing with a phenomenon that concerns the population as a whole? It would seem that this is indeed the manifestation of a contextual effect which, not only not measurable at the individual level, is not reducible to that level either. Studies have shown that immigrants are influenced by the risk profile of their country of residence, that is to say, that the cholesterol distribution curve of Japanese immigrants living in Finland tends to resemble that of the Fins. Genetic differences, though they may explain some of the difference, are far from capable of explaining its full extent; collective dietary habits, social norms - properties not reducible to the individual level—play an important role. ${ }^{27}$ An epidemiology that is overly focussed on the individual level risks committing what some have called the "individualistic fallacy" (or "atomistic fallacy"), that is to say, the presupposition that effects at the individual level can be entirely and exclusively explained in terms of individual characteristics. This error would be just as dangerous as the "ecological fallacy" (see above, Sect. 3.1), which threatens studies focussing on populations (Krieger, 1994, p. 899). ${ }^{28}$

Diverse currents-social epidemiology, ecological epidemiology, multi-level epidemiology — seek to take account of and better define ecological variables in their analyses. In order to understand what is at stake in these group variables, it is useful to distinguish between "derived" or "aggregated" variables and "integral" or "global" variables. "Derived" variables are in fact just simple summaries of observations made of individuals (average household income, average number of smokers in a population, etc.) and are generally easier to define and to obtain. "Integral" variables, by contrast, are those properties of a population for which there is no measurable analogue at the level of the individual (population density, level of social disorganization, accessibility of health services, social capital, herd immunity, etc.) (Diez-Roux, 1998; Morgenstern, 1995). These latter variables are claimed to be characteristics constitutive of the population and so irreducible to a lower level of organization. The difficulty lies in the definition and measurement of these variables, and that requires a great deal of empirical and theoretical groundwork.

With the introduction of the notion of a "social fact", the sociologist, Emile Durkheim, had already developed the idea of the relative autonomy of population phenomena and affirmed that a population, or a given society, may have its own specific characteristics. ${ }^{29}$ In the field of health, the study and definition of the ecological variable of "herd immunity" occurred well before the movement in favour of a return to a population perspective in epidemiology: its first appearance in a

\footnotetext{
27 See also the confirmations of Geoffrey Rose's thesis by Marmot and Mustard in (Evans et al., 2017).

${ }^{28}$ For a more detailed analysis and distinctions between ecological, atomist, individualist, psychological, and sociological fallacies, see Diez Roux (1998, p. 218-219).

29 In the analysis of suicide, first published in 1897, Durkheim showed that the level of suicide is not the simple aggregate of individual tendencies to commit suicide. On the contrary, the level reflects the social properties described: the underlying social values, a certain distribution of social relations, the moral significance accorded to the act of suicide, etc. An individual explanation or characterization of the phenomenon thus remains insufficient. (See Durkheim, 2013).
} 


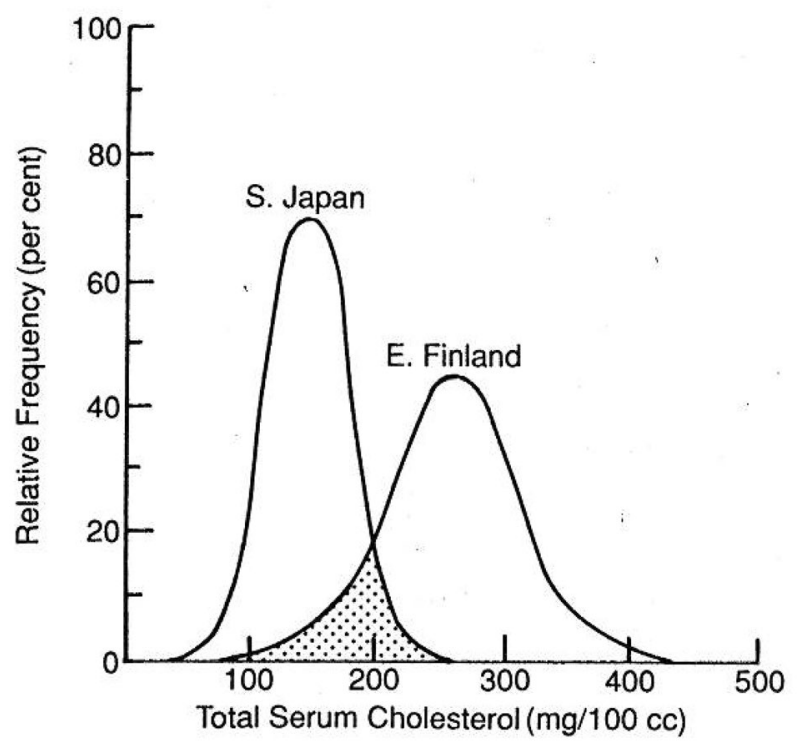

Fig. 1 The contrasting distributions of serum cholesterol in south Japan and eastern Finland (from Geoffrey Rose, 1992, p. 57, reproduced with permission)

medical publication is in an article by the American epidemiologists, Topley and Wilson (Topley \& Wilson, 1923) ${ }^{30}$, and the concept came initially from the English epidemiologist, Major Greenwood (1880-1949). Immunity at the level of the group is a global resistance to a given pathogen: there is a qualitative threshold, a percentage of immunized individuals, beyond which an infectious disease loses both its epidemic aspect and its contagiousness. By definition, it is a question here, Topley and Wilson explain, of a characteristic of a population which has no direct analogue at the individual level. There is certainly a tight link between the immunity of an individual and that of the group but the two phenomena must be treated separately. The presence and the proximity of immunized individuals indirectly protects those not immunized. It is thus a property constitutive of the population, distinct from the simple sum of individual immunities, which determines whether the contagious disease will endure. And this populational characteristic considerably influences what occurs at the individual level: the immunity of the population has an impact on the number of individuals of the population susceptible to be infected, that is to say, the risk of infection of an individual is tightly linked to the prevalence of the disease in the population in which it occurs and to the immunity of that population. Herd immunity thus gives an example of an interaction between different levels of organization that cannot be properly accounted for without prior recognition of their difference.

$\overline{30}$ For a review and historical analysis of this concept, see (Fine, 1993). 
If the existence of health properties specific to a population appears more obvious in the case of infectious diseases, because of the essentially relational dimension of their transmission, such properties have also been defined for other types of disease. Diseases whose aetiology is more complex, like cardiovascular diseases, are partly due to behaviour influenced by social and economic norms. In his book, Unhealthy Societies, Richard Wilkinson (1996) showed how the relation between wealth and health is different at the level of the population from at the individual level. At the population level, it's the distribution of income rather than its absolute level which is important and which most determines the health status of the populations of the most developed countries; this distribution has an influence on what he calls "social cohesion". He concludes from this that a society should be considered healthier than another when the income distribution is less inegalitarian. The notions of "social capital", "social network", "income distribution", and so on, are integral variables which allow one better to explain and describe the evolution of complex chronic diseases at the level of the population. ${ }^{31}$

\subsubsection{Population causality}

The existence of properties constitutive of a population could lead one to think that there exists a certain explanatory autonomy at the populational level. For Geoffrey Rose, if one needs both the individual level and the population level for the comparison and etiological analysis of health phenomena, it is because there can be different types of causality operative at these different levels. One may thus distinguish, he claims, the "cause of cases", that is to say, a factor that explains the occurrence of a diseases in an individual, from the "cause of incidence", which concerns the population. The question, "why do some individuals have higher serum cholesterol levels than others'? (cause of cases) is not the same and will not have the same answer as "why do the Finish have higher cholesterol than the Japanese"? (cause of incidence) (Rose, 1985, pp. 32-38). It is not a question of a simple difference between proximal and more distal causes, but rather of a qualitative difference and a difference of scale. If one recognized the existence of a causality specific to the population level, epidemiological analysis could play an explanatory and diagnostic role all of its own. Causal research based on statistical association would no longer be a simple preliminary to the analysis of the pathogenesis of diseases at the individual level by physiopathology.

Let us note that philosophical analysis of a probabilistic concept of causality and of the nature of causality in the theory of natural selection have given rise to a comparable distinction between two concepts of causality for the population and individual levels (Eells, 1991; Sober, 1984b). For the philosopher of biology, Elliott Sober, the distinction previously evoked between selection of and selection for refers to two types of causes: selection for refers to the causality of properties (population

\footnotetext{
31 These notions, some of which arise from sociology, have been the object of research in social epidemiology and call for a substantial work of elaboration and definition. On the notion of "social capital", see the debate in the International Journal of Epidemiology (2004, p. 627-700).
} 
level causality) and selection of designates causality at the level of events or objects (individual level causality). Probabilistic causality is the causality of properties. For Sober, a particularity of the theory of evolution is that it brings to light the causal efficacity of population properties; one of its important consequences is to make both possible and autonomous the scientific description of phenomena at the population level. Following on the heels of Ian Hacking's work on the autonomy of statistical laws (Hacking, 1990, pp. 180-188), Sober maintains that the population level of explanation does not require one to descend to a lower level of organization. ${ }^{32}$

In epidemiology, to undertake etiological analysis at the level of the population, it is necessary to rehabilitate ecologic studies and to reinforce the solidity of inferences at this level. After a better definition of ecological variables, this is the second main axis of the program of eco-social or multi-level epidemiology. Multi-level statistical techniques could prove to be particularly useful in this context. They model the relations of variables and of their effects on one other, while taking into account, in the statistical model, the level of organization at which the variable is measured. This guarantees a better control of bias, which could otherwise find its way into ecological analyses, and of the risk of ecological fallacy mentioned earlier (Duncan et al., 2018; Morgenstern, 1995). It could also allow one to test empirically the irreducibility of population level effects to the individual level. As the epidemiologist, Ana Diez Roux (2004, p. 109) observes: “[a] valuable outcome of the advent of multilevel models is that it has become increasingly common for epidemiologists to theorize regarding the possible health effects of group-level factors. (...) the recognition that a hierarchy of levels may be relevant to any health problem is a fundamental shift in the dominant biomedical and individual paradigm."

But does showing the constitutive properties of the population, as well as the explanatory autonomy of this level, suffice to guarantee an ontological autonomy and to justify a concept of population health? For the American epidemiologist, John Gordon, cited at the beginning of the article, the specific contribution of epidemiology to our understanding of disease lies in the fact that it is situated at the level of the population, with the population being understood as a level of organization with a relative autonomy and not as a simple statistical aggregate. John Gordon and Geoffrey Rose-as well as the epidemiologists who, following in their footsteps, defend the importance of a populational perspective in the analysis of health and disease phenomena-seem to maintain that, if a given population can possess specific and irreducible characteristics, it thus has a certain ontological unity, a certain form of individuality. In any case, it could not be apprehended as the simple sum of its members and their interactions. It is not a question, however, of identifying the population with an organism or of affirming the total independence of the individual and population levels. This is underlined by Rose when he tempers his allegiance to Durkheim (whom he had just cited): "[t]o assert such a complete independence between the characteristics of society as a whole and of its individual members is far too extreme, but in order to grasp the principles of public health one must understand

\footnotetext{
32 Sober (1984a, pp. 147-155) takes up the distinction of Lewontin (1983) between a "variational" or horizontal mode of explanation and a "developmental" or vertical level of explanation.
} 
that society is not merely a collection of individuals but is also a collectivity, and the behaviour and health of its individual members are profoundly influenced by its collective characteristics and social norms" (Rose, 1992, p. 62). It may be said, Rose concludes, that "healthiness is a characteristic of the population as a whole and not simply of its individual members" (p. 62). This perspective on the health of the population as a whole allows one to include the distribution of health outcomes within the group. Further, it is in this way that those who promote the recent current in favour of a population health approach - a current that defends the importance of considering population health as a whole and not as a simple aggregate of the health of individuals-literally define the concept as "the health outcomes of a group of individuals, including the distribution of such outcomes within the group" (Kindig \& Stoddart, 2003, p. 380). ${ }^{33}$ The importance given to the multi-level approach of epidemiology and to the different types of causality at the individual and at population levels are also central to the population health science defended by Katherine Keyes and Sandro Galea (2016).

Conceiving a health specific to and characteristic of the population does not therefore require one to consider it in opposition to individual health, but rather to articulate the two and to think about them conjointly (Giroux, 2020). If there is prior recognition of a relative autonomy of these two levels, one may then think about their independence and entanglement. In reality, as Arah (2009) has shown, neither individual health nor population health can be defined and identified without contextualizing the former inside the latter. As Diez Roux (2016, p. 619) has said about the recent current in favour of treating population health as a whole: "the population health approach (...) does not view the health of an individual in contrast to (or as distinct from) the health of a population but rather articulates how patterns of population health result from the dynamic and interacting relations between individuals, between individuals and their context, and between individuals and the services that they have access to and use."

\section{Conclusion}

I hope to have shown that the question of the pertinence and validity of a concept of "population health" or "collective health" is worth being examined once again, beyond the restriction of the concept of health to organic individuality established by Canguilhem. This is justified notably by the importance of taking account of the irreducibility of population level phenomena to the individual level, both for knowledge and for action, in the sense of effective interventions in public health and in the clinic. Herd

\footnotetext{
33 On this current, see footnote 7 above. This approach aims to renew public health, which is judged to be overly dependent on an individualist biomedical paradigm. The defence of the population health approach is at the heart of public health policy in Canada: "The Public Health Agency of Canada has identified population health as a key concept and approach for policy and program development aimed at improving the health of Canadians" (https:/www.canada.ca/en/public-health/services/health-promotion/ population-health/population-health-approach.html). For philosophical reflections on this approach and the defence of its importance, see (Valles, 2018).
} 
immunity and the distribution of health phenomena are good examples of this. The means offered by multi-level statistical techniques in epidemiology may nourish philosophical investigations into a concept of population health. These methods make it possible to take account of differences between levels of organization and to understand their interactions. Population and individual levels may thus be considered complementary both for analysis and for action, and may be studied from the perspective of their interactions. The individual level would thus be less exclusive, while still conserving an important role.

The relative autonomy of the populational level of analysis which emerges in this context should not, however, lead one to consider that the population has an ontological unity as strong as that of the individual organism. To use the concept of health with respect to a population requires a prior enrichment of our ontological concepts. Georges Canguilhem rejected the analogy between society and organism that Auguste Comte used for his analysis of health phenomena at the level of society. In philosophy of biology, the loosening of the link between the notions of the individual and the organism, along with evolutions in the concept of individuality, renew reflection on the ontological status of supra-organic levels of organization. Different degrees of the ontological unity of entities could be envisaged.

It may be concluded that an examination of the perspectives adopted in the framework of eco-social and multi-level epidemiology, as well as the recent developments in favour of a "population health approach" and population health science show that the study of populational health phenomena in themselves, and of a concept of health specific to populations, are more pertinent and more necessary than Canguilhem would seem to have envisaged. This reflection could be further enriched through a dialogue with recent debates about the extension of the concept of health to other entities, such as planets or ecosystems. And it has implications for the debate between collectivists versus individualists in the philosophy of public health. It is also relevant for the way in which public health interventions are designed by reinforcing the importance of the population strategy of prevention and intervention, dear to Geoffrey Rose (1992), a dimension that tends to be neglected in the personalised or precision medicine era (Giroux, 2021).

Acknowledgements I would like to offer special thanks to Pierre-Olivier Méthot, without whom the present English-language version of this article would never have been written. I thank David Teira who played a key role at the end of the process. I would like to thank Antoine C. Dussault for his re-reading and for our exchanges on the subject of the applicability of the concept of health beyond the context of individual organisms. I also warmly thank the blind reviewers for their very judicious remarks and advice. And last but not least, I thank Henry Dicks whohas made possible the English-language version of this text.

Funding Institut de Recherches Philosophiques de Lyon.

\section{Declarations}

Conflict of interest Authors declares that they have no conflict of interest. 


\section{References}

Arah, O. A. (2009). On the relationship between individual and population health. Medicine, Health Care and Philosophy, 12(3), 235-244.

Ariew, A. (2008). Population thinking. In M. Ruse (Ed.), The Oxford handbook of philosophy of biology (pp. 64-86). Oxford University Press.

Berkman, L. F., \& Kawachi, I. (2000). Social epidemiology. Oxford University Press.

Bouchard, F., \& Huneman, P. (Eds.), (2013). From groups to individuals. The MIT Press.

Brandon, R. (1982). The levels of selection. PSA Proceedings of the Biennial Meeting of the Philosophy of Science Association, 1982(1), 315-323. https://doi.org/10.1086/psaprocbienmeetp.1982.1. 192676

Buller, D. J. (Ed.). (1999). Function, selection, and design. State University of New York Press.

Canguilhem, G. (1988a). Le statut épistémologique de la médecine. History and Philosophy of the Life Sciences, 10, 15-29.

Canguilhem, G. (1988b). The question of normality in the history of biological thought. In G. Canguilhem (Ed.), Ideology and rationality in the history of the life sciences (pp. 125-145). MIT Press.

Canguilhem, G. (1991). The normal and the pathological (new edition). Zone Books.

Canguilhem, G. (1994). Études d'histoire et de philosophie des sciences concernant les vivants et la vie. Vrin.

Canguilhem, G. (2008). The normal and the pathological. In G. Canguilhem (Ed.), Knowledge of life (pp. 121-133). Fordham University Press.

Canguilhem, G. (2012a). Disease. In G. Canguilhem (Ed.), Writings on medicine (pp. 34-42). Fordham University Press.

Canguilhem, G. (2012b). Health: popular concept and philosophical question. In G. Canguilhem (Ed.), Writings on medicine (pp. 43-52). Fordham University Press.

Canguilhem, G. (2012c). The problem of regulation in the organism and in the society. In G. Canguilhem (Ed.), Writings on medicine (pp. 67-78). Fordham University Press.

Dawkins, R. (2016). The selfish gene. Oxford University Press.

Diez Roux, A. V. (2004). The study of group-level factors in epidemiology: Rethinking variables, study designs, and analytical approaches. Epidemiologic Reviews, 26, 104-111. https://doi.org/10.1093/ epirev/mxh006

Diez Roux, A. V. (2016). On the distinction-Or lack of distinction-between population health and public health. American Journal of Public Health, 106(4), 619-620. https://doi.org/10.2105/AJPH. 2016.303097

Diez-Roux, A. V. (1998). Bringing context back into epidemiology: Variables and fallacies in multilevel analysis. American Journal of Public Health, 88(2), 216-222.

Duncan, D. T., Kawachi, I., \& Roux, A. V. D. (Eds.), (2018). Neighborhoods and health (second edition). Oxford University Press.

Durkheim, É. (2013). Le suicide: Étude de sociologie. Introduction de Serge Paugam (14e édition). Presses Universitaires de France.

Eells, E. (1991). Probabilistic causality. Cambridge University Press.

Evans, R. G., Barer, M. L., Marmor, T. R., \& Barer, M. (2017). Why are some people healthy and others not? Routledge.

Evans, R. G., \& Stoddart, G. L. (1990). Producing health, consuming health care. Social Science \& Medicine, 31(12), 1347-1363. https://doi.org/10.1016/0277-9536(90)90074-3

Fine, P. E. (1993). Herd immunity: History, theory, practice. Epidemiologic Reviews, 15(2), $265-302$. https://doi.org/10.1093/oxfordjournals.epirev.a036121

Galea, S., \& Link, B. G. (2013). Six paths for the future of social epidemiology. American Journal of Epidemiology, 178(6), 843-849.

Gayon, J. (1998). The concept of individuality in Canguilhem's philosophy of biology. Journal of the History of Biology, 31(3), 305-325. https://doi.org/10.1023/A:1004312823993

Gayon, J., \& de Ricqlès, A. (Eds), (2010). Les fonctions: Des organismes aux artefacts. Presses Universitaires de France.

Ghiselin, M. T. (1974). A radical solution to the species problem. Systematic Zoology, 23(4), 536-544. https://doi.org/10.2307/2412471 
Giroux, É. (2008a). L'épidémiologie entre population et individu: Quelques clarifications à partir de la notion de 'pensée populationnelle.' Bulletin d'histoire et d'épistémologie des sciences de la vie, 1 , $37-52$.

Giroux, É. (2008b). N'y a-t-il de santé que de l'individu? In A. Fagot-Largeault, C. Debru, M. Morange (Dir.), H-J. Han (Ed.), Philosophie et médecine, hommage à Georges Canguilhem. (pp. 171-193). Vrin.

Giroux, É. (2010). Après Canguilhem: Définir la santé et la maladie. Presses Universitaires de France.

Giroux, É. (2015). Epidemiology and the bio-statistical theory of disease: A challenging perspective. Theoretical Medicine and Bioethics, 36(3), 175-195.

Giroux, É. (2020). Is personalized medicine humanist? Archives de philosophie, 83(4), 59-82.

Giroux, É. (2021). La « santé publique de précision »: Un changement de paradigme pour la santé publique ou la perte de son âme? Actualité et Dossier En Santé Publique (ADSP), 112.

Goldstein, K. (1939). The organism: A holistic approach to biology derived from pathological data in man. American Pathological Series.

Gordon, J. E. (1950). Epidemiology: Old and new. Journal of the Michigan State Medical Society, 49, 194-199.

Guay, A., \& Pradeu, T. (Eds.). (2015). Individuals across the sciences. Oxford University Press.

Hacking, I. (1990). The taming of chance. Cambridge University Press. https://doi.org/10.1017/CBO97 80511819766

Hull, D. L. (1978). A matter of individuality. Philosophy of Science, 45(3), 335-360.

Huneman, P. (2010). Assessing the prospects for a return of organisms in evolutionary biology. History and Philosophy of the Life Sciences, 32(2-3), 341-371.

Keyes, K. M., \& Galea, S. (2016). Population health science. Oxford University Press.

Keys, A. (1970). Coronary heart disease in seven countries. American Heart Association Monograph No. 29.

Keys, A., \& White, P. D. (1956). Cardiovascular epidemiology. Hoeber-Harper.

Kindig, D., \& Stoddart, G. (2003). What is population health? American Journal of Public Health, 93(3), 380-383. https://doi.org/10.2105/ajph.93.3.380

Kingma, E. (2017). Disease as scientific and as value-laden concept. In T. Schramme \& S. Edwards (Eds.), Handbook of the philosophy of medicine (pp. 45-63). Netherlands: Springer. https://doi.org/ 10.1007/978-94-017-8688-1_75

Krieger, N. (1994). Epidemiology and the web of causation: Has anyone seen the spider? Social Science \& Medicine, 39(7), 887-903.

Krieger, N. (2001). Theories for social epidemiology in the 21st century: An ecosocial perspective. International Journal of Epidemiology, 30(4), 668-677. https://doi.org/10.1093/ije/30.4.668

Krohs, U., \& Kroes, P. (2009). Functions in biological and artificial worlds: Comparative philosophical perspectives. MIT Press.

Lewontin, R. C. (1970). The units of selection. Annual Review of Ecology and Systematics, 1(1), 1-18. https://doi.org/10.1146/annurev.es.01.110170.000245

Lewontin, R. C. (1983). Darwin's revolution. The New York Review of Books, 30, 21-27.

McMichael, A. J. (1999). Prisoners of the proximate: Loosening the constraints on epidemiology in an age of change. American Journal of Epidemiology, 149(10), 887-897.

Méthot, P. O. (Ed.). (2020a). Vital norms. Canguilhem's 'The normal and the pathological' in the twentyfirst century. Hermann.

Méthot, P.-O. (2020b). Georges Canguilhem and 'the problem of evolution' in The normal and the pathological. In P.-O. Méthot (Ed.), Vital Norms. Canguilhem's 'The normal and the pathological' in the twenty-first century (pp. 137-181). Hermann.

Morgenstern, H. (1995). Ecologic studies in epidemiology: Concepts, principles, and methods. Annual Review of Public Health, 16, 61-81. https://doi.org/10.1146/annurev.pu.16.050195.000425

Murphy, D. (2008). Concepts of disease and health. The Stanford Encyclopedia of Philosophy.

Nicholson, D. J. (2014). The return of the organism as a fundamental explanatory concept in biology. Philosophy Compass, 9(5), 347-359. https://doi.org/10.1111/phc3.12128

Pett, K. D., Willett, W. C., Vartiainen, E., \& Katz, D. L. (2017). The seven countries study. European Heart Journal, 38(42), 3119-3121. https://doi.org/10.1093/eurheartj/ehx603

Pradeu, T., \& Ludwig, P. (Eds.), (2008). L'individu. Perspectives contemporaines. Vrin.

Robinson, W. S. (1950). Ecological correlations and the behavior of individuals. American Sociological Review, 15(3), 351-357. https://doi.org/10.2307/2087176 
Rose, G. (1985). Sick individuals and sick populations. International Journal of Epidemiology, 14(1), 32-38. https://doi.org/10.1093/ije/14.1.32

Rose, G. (1992). The strategy of preventive medicine. Oxford University Press.

Rothman, K. J. (1986). Modern epidemiology. Little, Brown.

Schramme, T. (2015). Health as notion in public health. In T. Schramme \& S. Edwards (Eds.), Handbook of the philosophy of medicine (pp. 1-10). Netherlands: Springer. https://doi.org/10.1007/978-94017-8706-2_49-1

Schwartz, S. (1994). The fallacy of the ecological fallacy: The potential misuse of a concept and the consequences. American Journal of Public Health, 84(5), 819-824. https://doi.org/10.2105/ajph.84.5. 819

Sholl, J. (2020). Plastic, variable, and constructive: Renewing canguilhem's biological normativity. In P.-O. Méthot (Ed.), Vital norms. Canguilhem's 'The normal and the pathological' in the twenty-first century (pp. 255-294). Hermann.

Sober, E. (1984a). The nature of selection: Evolutionary theory in philosophical focus. University of Chicago Press.

Sober, E. (1984b). Two concepts of cause. PSA Proceedings of the Biennial Meeting of the Philosophy of Science Association, 1984, 405-424.

Susser, M. (1985). Epidemiology in the United States after World War II: The evolution of technique. Epidemiologic Reviews, 7, 147-177. https://doi.org/10.1093/oxfordjournals.epirev.a036280

Susser, M. (1998). Does risk factor epidemiology put epidemiology at risk? Peering into the future. Journal of Epidemiology and Community Health, 52(10), 608-611.

Susser, M., \& Susser, E. (1996). Choosing a future for epidemiology: II. From black box to Chinese boxes and eco-epidemiology. American Journal of Public Health, 86(5), 674-677.

Topley, W. W. C., \& Wilson, G. S. (1923). The spread of bacterial infection. The problem of herd-immunity. The Journal of Hygiene, 21(3), 243-249.

Valles, S. A. (2018). Philosophy of population health: Philosophy for a new public health era. Routledge.

Wilkinson, R. G. (1996). Unhealthy societies. Routledge London.

Williams, G. (1966). Adaptation and natural selection. Princeton University Press.

Wilson, D. S., \& Sober, E. (1989). Reviving the superorganism. Journal of Theoretical Biology, 136(3), 337-356. https://doi.org/10.1016/s0022-5193(89)80169-9

Wimsatt, W. C. (1980). The units of selection and the structure of the multi-level genome. PSA: Proceedings of the Biennial Meeting of the Philosophy of Science Association, 1980, 122-183.

Publisher's Note Springer Nature remains neutral with regard to jurisdictional claims in published maps and institutional affiliations. 